\title{
Penentuan Potensi Sumber Daya Batuan Mangan Menggunakan Metode Geolistrik Tahanan Jenis Konfigurasi Wenner di Buraen, Amarasi Selatan-Kabupaten Kupang
}

\section{Regina Seran ${ }^{a}$}

${ }^{a}$ Fakultas Pertanian, Universitas Timor, Kefamenanu, TTU - NTT, Indonesia, email: reginaseran@ gmail.com ${ }^{a}$ Faculty of Agriculture, Timor University, Kefamenanu, TTU - NTT, Indonesia, email: reginaseran@gmail.com

\section{Article Info} Abstrak

Article history:

Received 15 Mei 2019

Received in revised form 25 Mei 2019

Accepted 26 Juni 2019

Telah dilakukan penelitian geolistrik tahanan jenis konfigurasi Wenner secara Sounding di Buraen kecamatan Amarasi Selatan kabupaten Kupang dengan luas lokasi penelitan $2025 \mathrm{~m}^{2}$. Tujuan penelitian ini untuk mengetahui pola penyebaran batuan mangan dan kisaran nilai tahanan jenis batuan mangan serta menghitung potensi sumber daya batuan mangan di lokasi penelitian. Pengolahan data menggunakan program IP2WIN untuk mengetahui kedalaman, ketebalan dan jumlah perlapisan serta harga tahanan jenis batuan. Program Surfer 9 untuk menghitung potensi sumber daya batuan mangan. Hasil Penelitan memperlihatkan penyebaran batuan mangan hampir ada diseluruh DOI https://doi.org/10.32938/slk.v2i1.680 Keywords:

Tahanan jenis

Potensi sumber daya mangan lintasan pengukuran dengan ketebalan bervariasi. Berdasarkan analisis lapisan batuan, nilai tahanan jenis antara $4 \Omega \mathrm{m}-31,9 \Omega \mathrm{m}$ diduga merupakan lapisan batuan mangan. Hasil perhitungan volume batuan mangan sebesar $36,707 \mathrm{~m}^{3}$ dan merupakan sumber daya hipotetik Amarasi Kupang

\section{Pendahuluan}

NTT merupakan salah satu propinsi di Indonesia yang memiliki potensi bahan galian tambang. Hal ini diperkuat oleh adanya kegiatan eksplorasi bahan tambang yang telah dilakukan di beberapa daerah yang ada di Propinsi NTT. Hasil galian tambang itu terdiri dari 3 golongan yakni bahan galian golongan A (Nikel, Batu Bara, Timah), B (Emas, Tembaga, Besi, Mangan) dan bahan galian golongan C (marmer, batuan gamping, granit, tanah liat, dan lain sebagainya). Bahan-bahan galian tersebut tersebar di Propinsi Nusa Tenggara Timur, (Dinas pertambangan NTT, 1995).

Mangan di alam berupa logam berwarna putih-kelabu dan mudah teroksidasi, diantaranya terdapat dalam bentuk $\mathrm{MnO}_{3}$. Mangan banyak digunakan dalam industri besi dan baja serta baterai. Batuan mangan bisa dikatakan layak jual di pasaran internasional jika minimal mengandung sekitar 35\% unsur mangan. Batuan mangan Indonesia saat ini kebanyakan diekspor untuk memenuhi kebutuhan industri di China, (PT. GeoAtlas Indonesia, 2011)

Endapan utama bijih mangan dalam mineralogi yaitu pirolusit dan psilomelan. Mangan berkomposisi oksida lainnya, namum tidak berperan sebagai mineral utama dalam cebakan bijih adalah braunit dan manganit Kedua mineral ini dijumpai dalam urat bijih atau cebakan sekunder, (Graha, 1987).

Sumber mangan yang komersial umumnya berasal dari cebakan sedimenter terpisah dari aktivitas volkanik dan cebakan akumulasi residual, (Park dan Mac Diarmid dalam Winarti, 2009).

Eksplorasi mangan telah sering dilakukan dengan menggunakan berbagai metode, salah satu metode geofisika yang sering digunakan adalah metode geolistrik. Metode geolistrik merupakan salah satu metode geofisika yang digunakan untuk eksplorasi sumber daya alam yang terdapat di dalam lapisan bumi berdasarkan tahanan jenis yang terukur. Metode ini menggunakan prinsip-prinsip dari sifat kelistrikan bumi untuk melihat struktur yang tersembunyi.

Penentuan tahanan jenis mangan pada daerah-daerah di Nusa Tenggara Timur telah banyak dilakukan sebelumnya, misalnya pada penelitian yang dilakukan oleh Emanuel Banggut berskala laboratorium mendapatkan kesimpulan bahwa kisaran nilai tahanan jenis di daerah kabupaten TTU yaitu antara $1 \Omega \mathrm{m}-32,5 \Omega \mathrm{m}$, (Banggut, 2011).

Buraen merupakan salah satu kelurahan di Kecamatan Amarasi Selatan-Kabupaten Kupang - Nusa Tenggara Timur yang merupakan salah satu daerah yang memiliki potensi batuan mangan. Penduduk yang bekerja sebagai penambang batu mangan adalah petani, yang pada saat bukan musim tanam mengalihkan pekerjaan sebagai penambang batu mangan Dalam proses penggalian dilakukan tanpa mengetahui secara pasti penyebaran mangan dan volume dari potensi sumber daya mangan. Perlu dilakukan eksplorasi penyebaran batuan mangan tersebut ke arah vertikal dan horizontal serta perhitungan potensi sumber daya mangan baik di lapangan secara langsung maupun dalam skala laboratorium.

2. Metode

Penelitian ini dilakukan pada bulan September 2011 di kelurahan Buraen kecamatan Amarasi Selatan Kabupaten Kupang menggunakan metode geolistrik tahanan jenis konfigurasi Wenner sounding dengan luas lokasi penelitian $2025 \mathrm{~m}^{2}$. Alat yang digunakan adalah1 set resistivitimeter OYO, sumber tegangan $(a c c u)$ dan GPS.
Metode Analisa Data

1. Menghitung besarnya faktor geometri $(K)$ serta tahanan jenis semu $\left(\rho_{\mathrm{s}}\right)$ menggunakan persamaan $K=2 \pi a$ (Damtoro, 2007) dan $\rho_{s}=K \frac{\Delta V}{I}$ (Telford et al, 1990), untuk setiap lintasan.

2. Hasil pengukuran dan perhitungan berupa $\mathrm{I}, \Delta \mathrm{V}, \mathrm{R}, \mathrm{K}$ dan $\rho_{\mathrm{s}}$ untuk setiap lintasan dijadikan input dalam program IP2WIN.

3. Menginterpretasi data untuk masing-masing lintasan yang dibuat pada saat pengukuran dilapangan.

4. Korelasi antar lintasan untuk mendapatkan gambaran luasan area yang di interpretasi berpotensi terdapat sumber daya mangan.

5. Menghitung potensi sumber daya mangan dengan program Surfer 9 .

\section{Hasil dan Pembahasan}

Pemodelan tahanan jenis dilakukan dengan cara mencatat nilai kuat arus yang diinjeksikan dan perubahan beda potensial yang terukur dengan menggunakan konfigurasi Wenner. Pengambilan data pada 10 lintasan dimana jarak antar lintasan 5 meter serta panjang lintasan penancapan elektroda 195 meter. Dari 10 lintasan tersebut, masing-masing lintasan diambil 10 titik sounding yang berjarak 5 meter. Data yang diperoleh yaitu nilai kuat arus dan beda potensial digunakan untuk menghitung nilai Tahanan jenis semu $\left(\rho_{s}\right)$. Harga Tahanan jenis semu yang didapatkan, kemudian diolah dengan Software IP2WIN. Dari Software tersebut didapatkan model tahanan jenis bawah permukaan di sepanjang lintasan dan kedalaman lapisan. Model distribusi Tahanan jenis bawah permukaan dapat mencerminkan kondisi bawah permukaan di sepanjang lintasan pengukuran, sehingga dapat dilakukan interpretasi kondisi litologi bawah permukaannya. Hasil program IP2WIN untuk 10 lintasan yang menunjukkan kedalaman, ketebalan dan jumlah perlapisan serta harga tahanan jenis batuan dapat dilihat pada Gambar 1.

Kisaran nilai tahanan jenis sebenarnya untuk semua lintasan antara $0.0131 \Omega \mathrm{m}-1279 \Omega \mathrm{m}$ serta kedalaman duga 65 meter. Kisaran nilai Tahanan Jenis sebenarnya dari setiap lintasan dapat dilihat pada tabel 1.

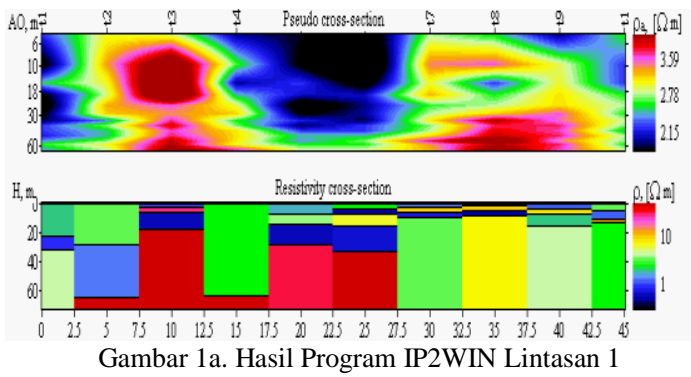




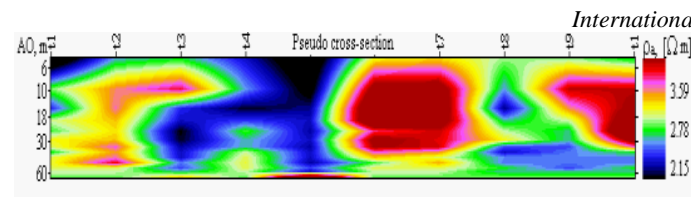

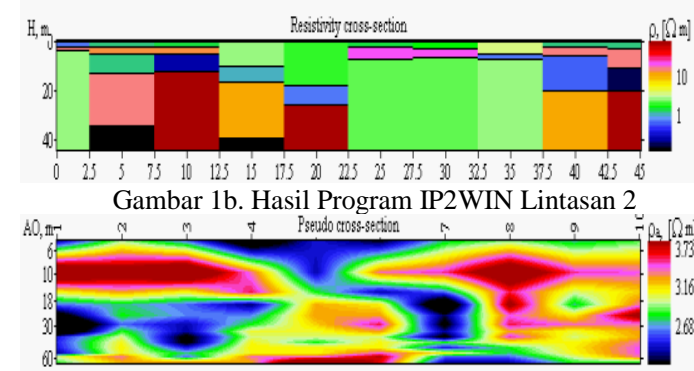
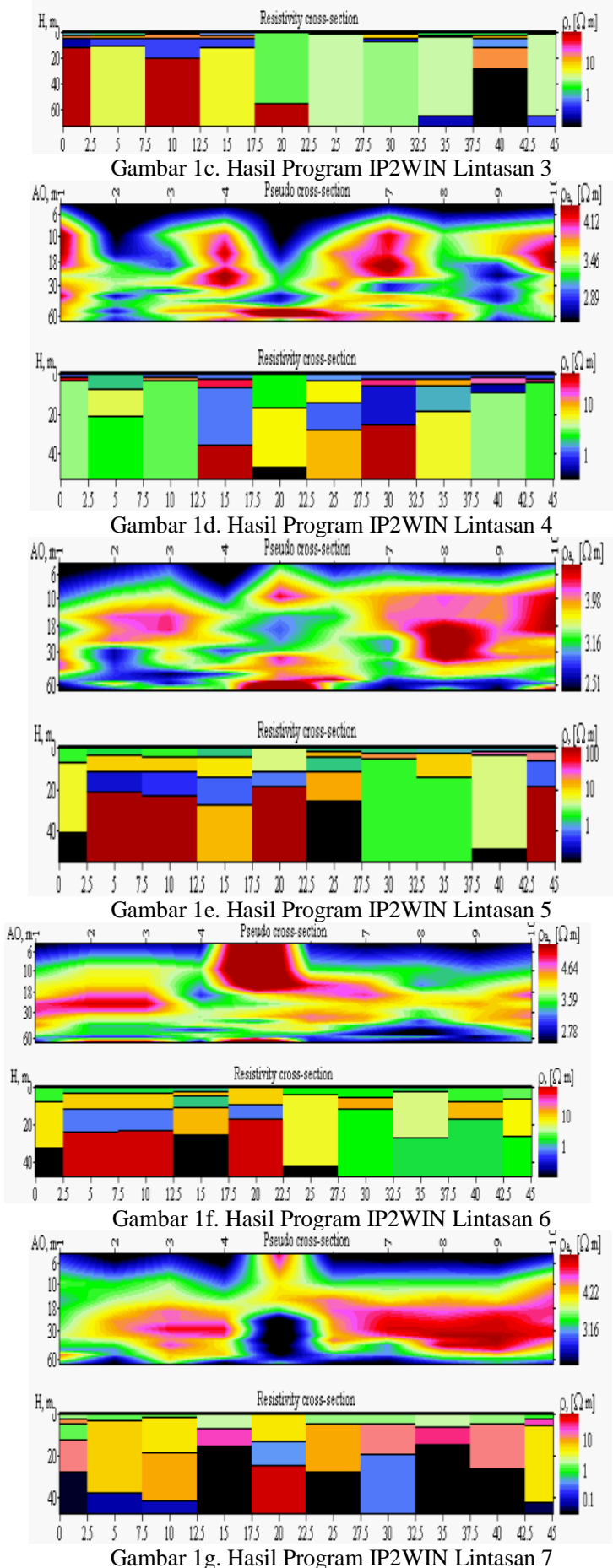

Gambar 1g. Hasil Program IP2WIN Lintasan 7
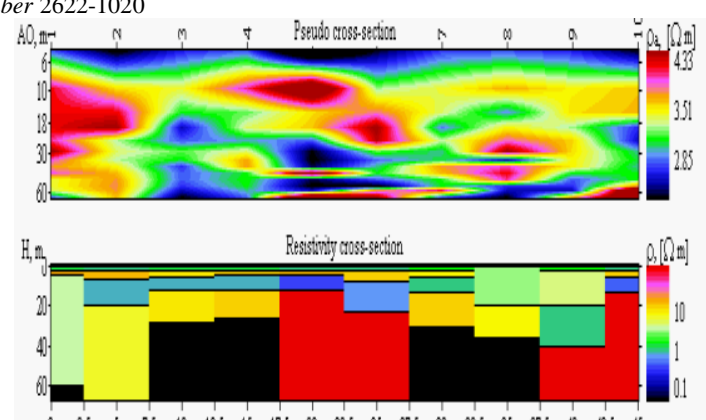

$\begin{array}{lllllllllllllllllll}0 & 25 & 5 & 75 & 10 & 125 & 15 & 175 & 20 & 225 & 25 & 275 & 30 & 325 & 35 & 335 & 40 & 45 & 4\end{array}$ Gambar 1h. Hasil Program IP2WIN Lintasan 8
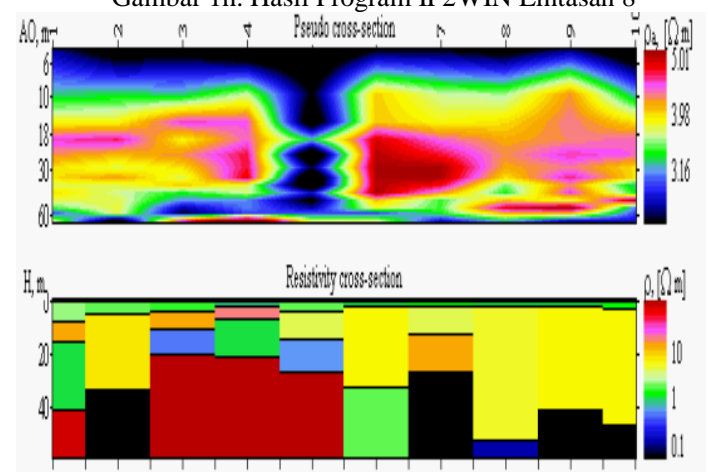

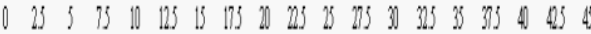
Gambar 1i. Hasil Program IP2WIN Lintasan 9
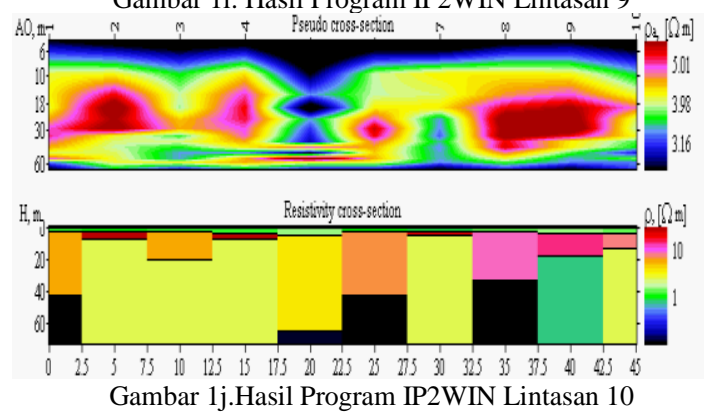

Tabel 1. Sebaran Nilai Tahanan Jenis

\begin{tabular}{|c|c|}
\hline Lintasan Ukur & Nilai Tahanan Jenis Sebenarnya $(\Omega \mathrm{m})$ \\
\hline I & $0.553-461$ \\
\hline II & $0.038-722$ \\
\hline III & $0.0323-1029$ \\
\hline IV & $0.108-230$ \\
\hline $\mathrm{V}$ & $0.0377-1279$ \\
\hline VI & $0.0185-896$ \\
\hline VII & $0.0131-430$ \\
\hline VIII & $0.0161-976$ \\
\hline IX & $0.0143-713$ \\
\hline$X$ & $0.213-31.8$ \\
\hline
\end{tabular}

Berdasarkan dasar-dasar interpretasi dan nilai tahanan jenis yang diperoleh, dicocokkan dengan tabel tahanan jenis batuan dan mineral Loke, (1999) maka lapisan batuan di lokasi penelitian dapat diduga terdiri atas 4 jenis lapisan batuan yaitu lapisan Clay bercampur Mangan, lapisan Mangan, lapisan Shale dan lapisan Limestone. Penjelasan untuk setiap lapisan batuan, sebagai berikut.

\section{Lapisan Clay Bercampur Mangan}

Lapisan Clay bercampur mangan merupakan lapisan yang paling dominan di permukaan dan menyebar di semua lintasan pengukuran dengan nilai tahanan jenis antara $0,0131 \Omega \mathrm{m}-3,95 \Omega \mathrm{m}$. Lapisan ini berada pada permukaan hingga kedalaman 7 meter, namun pada beberapa titik pengukuran mencapai kedalaman 28 meter bahkan mencapai kedalaman 65 meter. Lapisan Clay bercampur mangan juga ditemukan selang - seling di antara lapisan mangan dengan ketebalan minimum 2,16 meter dan ketebalan maksimum 61,6 meter. Clay adalah unsur utama tanah dan memiliki ukuran yang halus serta merupakan 
sedimen lepas sehingga nilai tahanan jenisnya lebih kecil. Clay yang terbentuk pada daerah yang berbeda mempunyai kenampakan fisik yang berbeda pula.

\section{Lapisan Mangan}

Lapisan yang diduga merupakan lapisan mangan nilai tahanan jenisnya antara $4 \Omega \mathrm{m}-31,9 \Omega \mathrm{m}$ karena dalam analisa data ini mengacu pada hasil penelitian Banggut (2011) yang mendapatkan kisaran nilai tahanan jenis mangan antara $1-32,5 \Omega \mathrm{m}$. Akan tetapi dalam penelitian ini nilai tahanan jenis antara $1-3,9 \Omega$ m tidak termasuk dalam kisaran nilai tahanan jenis lapisan yang diduga mangan karena dari dari pengamatan di lokasi diduga dalam kisaran nilai tahanan jenis lapisan Clay bercampur mangan. Lapisan yang diduga sebagai mangan ditemukan pada semua lintasan dengan ketebalan yang beragam, hanya pada beberapa titik tidak ditemukan lapisan ini tapi hanya terdapat lapisan Clay bercampur mangan. Lapisan ini berada pada kedalaman 1,71 meter hingga mencapai kedalaman 65 meter.

\section{Lapisan Shale}

Lapisan ini ditemukan pada lintasan I di titik pengukuran 2 dengan nilai tahanan jenis $41,8 \Omega \mathrm{m}$ pada kedalaman di bawah 65 meter. Lapisan shale merupakan batuan endapan (sedimen) yang terbentuk dari endapan Clay dan mudah pecah sehingga nilai tahanan jenisnya lebih kecil dari lapisan Limestone.

\section{Lapisan Limestone}

Memiliki nilai tahanan jenis antara $84,7 \Omega \mathrm{m}-1279 \Omega \mathrm{m}$ dan berada pada kedalaman dibawah 11,9 meter sampai ada yang berada pada kedalaman dibawah 63,4 meter. Lapisan ini ditemukan pada titik - titik tertentu pada setiap lintasan kecuali lintasan 10 tidak ditemukan lapisan Limestone. Lapisan ini terbentuk dari proses pengendapan atau sedimentasi lapisan-lapisan tanah dan zat-zat kimia yang dihanyutkan oleh air serta memiliki tekstur bervariasi antara rapat, berbutir, kasar dan Kristal. Lapisan limestone padat dan merupakan sedimen kompak sehingga nilai tahanan jenisnya lebih besar.

Dari pengelompokan lapisan batuan di atas maka dapat dihitung volume lapisan mangan di lokasi penelitian dengan program Surfer 9. Input data terdiri dari dua yaitu data untuk permukaan atas lapisan mangan dan permukaan bawah lapisan mangan. Permukaan atas lapisan mangan input kedalamannya adalah batas atas lapisan mangan dan permukaan bawah lapisan mangan input kedalamannya adalah batas bawah lapisan mangan.

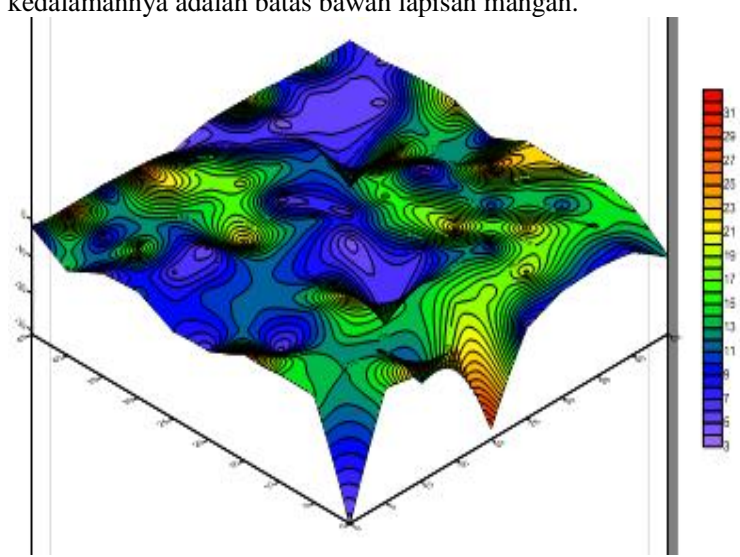

Gambar 2a. Gabungan kontur kedalaman dan kontur tahanan jenis lapisan mangan sebagai permukaan atas.

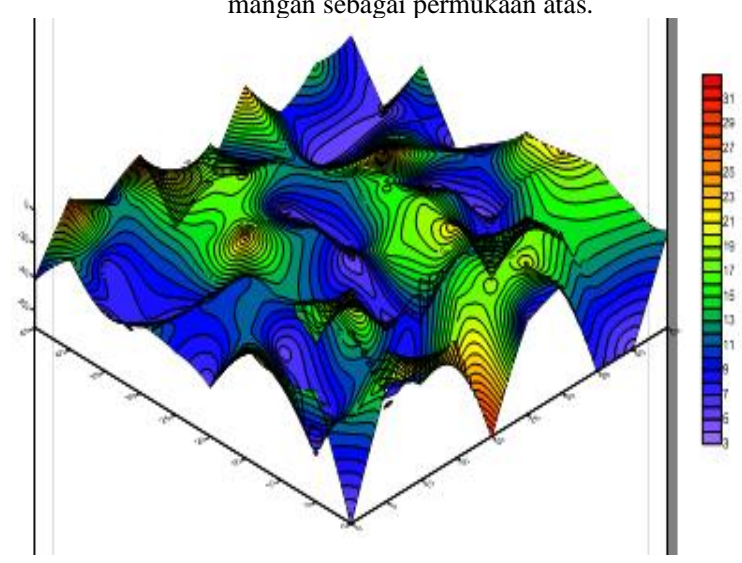

Gambar 2b. Gabungan kontur kedalaman dan kontur tahanan jenis lapisan mangan sebagai permukaan bawah

Setelah dilakukan proses grid volume dan diketahui volume dengan tiga metode perhitungan yaitu:

1. Perluasan Aturan Trapezoidal: $39.464 \mathrm{~m}^{3}$

2. Perluasan Aturan Simpson 1/3: $39.467 \mathrm{~m}^{3}$

3. Perluasan Aturan Simpson $3 / 8: 39.465 \mathrm{~m}^{3}$

Pada lintasan ukur I sampai lintasan ukur VIII terdapat beberapa titik pada kedalaman tertentu diantara upper surface dan lower surface yang tidak terdapat mangan. Untuk menghitung volume bersih dari mangan maka perlu menghitung volume dari bagian yang kosong tersebut. Volume bersih merupakan selisih antara volume seluruh dikurangi volume bagian yang kosong. Untuk menghitung volume bagian yang kosong maka dimasukan input data seperti langkah di atas akan tetapi data yang dimasukkan adalah data upper surface dan lower surface dari bagian yang kosong. Setelah dilakukan grid volume diperoleh volume sebagai berikut:

1. Perluasan Aturan Trapezoidal : $2.758 \mathrm{~m}^{3}$

2. Perluasan Aturan Simpson $1 / 3: 2.758 \mathrm{~m}^{3}$

3. Perluasan Aturan Simpson $3 / 8: 2.758 \mathrm{~m}^{3}$

Jadi dari hasil di atas diperoleh volume bersih mangan dilokasi penelitian yakni:

1. Perluasan Aturan Trapezoidal : $36.706 \mathrm{~m}^{3}$

2. Perluasan Aturan Simpson 1/3: $36.709 \mathrm{~m}^{3}$

3. Perluasan Aturan Simpson $3 / 8: 36.707 \mathrm{~m}^{3}$

Volume rata-rata dari ketiga metode perhitungan diatas adalah $36.707 \mathrm{~m}^{3}$ Karena luas lokasi penelitian adalah $2025 \mathrm{~m}^{2}$ dan kedalaman duga maksimum 65 meter maka volume total lokasi penelitian adalah $131.625 \mathrm{~m}^{3}$. Jika dipersentasikan maka volume mangan yang diduga adalah $27.88 \%$ dari volume total. Hasil perhitungan volume ini adalah dengan tingkat keyakinan geologi pada survei tinjau sehingga diistilahkan sebagai sumber daya hipotetik dan bukan disebut sebagai cadangan (BSN, 1998).

\section{Simpulan}

1. Nilai tahanan jenis di lokasi penelitian berdasarkan hasil invers program IP2WIN diseluruh titik pengukuran menunjukkan nilai yang bervariasi yakni antara $0.0131 \Omega \mathrm{m}-1279 \Omega \mathrm{m}$ serta kedalaman duga maksimum 65 meter.

2. Setelah dianalisis, lapisan batuan di lokasi penelitian dikelompokkan atas Empat jenis lapisan batuan yaitu lapisan batuan Clay bercampur mangan dengan nilai tahanan jenis antara $0.0131 \Omega \mathrm{m}-3.95 \Omega \mathrm{m}$, lapisan mangan memiliki nilai tahanan jenis antara $4 \Omega \mathrm{m}-31.9 \Omega \mathrm{m}$, lapisan Shale nilai tahanan jenisnya $41.8 \Omega \mathrm{m}$ dan lapisan limestone dengan nilai tahanan jenis antara $84.7 \Omega m-1279 \Omega m$.

3. Pola penyebaran mangan di lokasi penelitian ada diseluruh lintasan hanya pada titik-titik tertentu tidak terdapat mangan, serta kedalaman mangan berbeda-beda. Volume potensi sumber daya batuan mangan di lokasi penelitian setelah dihitung dengan program Surfer 9 adalah sebesar $36.707 \mathrm{~m}^{3}$

Pustaka

Badan Standardisasi Nasional-BSN.1998. Klasifikasi Sumberdaya Mineral dan Cadangan. Standar Nasional Indonesia Amandemen 1 - SNI 13-4726-1998 Banggut, E. 2011. Penentuan Resistivitas Batuan Mangan Di Daerah Kabupaten TTU Menggunakan Metode Geolistrik Dalam Skala Laboratorium-Skripsi S1.Jurusan Fisiska-Fakultas Sains dan Teknik-Universitas Nusa Cendana, Kupang

Damtoro,2007.Geofisika. http://www.geolistrik.com. 24 agustus 2011

Dinas Pertambangan NTT. 1995. Laporan Akhir : Pemetaan Semi Mikro Bahan Galian Golongan C di Kabupaten Dati II Ngada Propinsi Daerah Tingkat I NTT. PT Gradatu Engineering Consultan

Graha, D.S. 1987. Batuan dan Mineral. Bandung: NOVA.

Hendrajaya, L \& Arif, I. 1990. Geolistrik tahanan Jenis. Laboratorium Fisika Bumi Jurusan Fisika-FMIPA: ITB

Loke, M. H. 1999. Time-Lapse Resistivity Imaging Inversion. Penang, malaysia. PT. GeoAtlas Indonesia. 2011. Pengetahuan Mineral di Indonesia. Jakarta: Integrated Geosciences Exploration Services.

Telford, W.M., L.P. Geldart, , R.E. Sheriff, dan D.A. Keys. 1990. Applied Geophysic. London : Cambridge University Press.

Winarti. 2009. Studi Induced Polarization (IP) untuk Eksplorasi Mineral Mangan di Daerah Srati, Kecamatan Ayah, Kabupaten Kebumen, Jawa Tengah. Yogyakarta : Sekolah Tinggi Teknologi Nasional. 